\title{
Green building investment control system based on a three-dimensional parametric model of the green building
}

\author{
Daria Monastyreva ${ }^{1, *}$ and Natalia Astafieva ${ }^{1}$ \\ ${ }^{1}$ Peter the Great St. Petersburg Polytechnic University, Polytechnicheskaya, 29, 195251, Saint \\ Petersburg, Russia
}

\begin{abstract}
Investment in construction projects is a rather complex process. The customer of construction product, as a rule, is also its investor and for him the systematization of information about the construction process is a necessity. Construction investment control (CIC) is an integral part of the building construction process. Such control is a separate service that is necessary for the customer to objectively understand the installed work volumes and forecast deadlines. Completed construction and installation works are confirmed by acts of acceptance of the completed works, which are subsequently the basis for payment for the work done. In this paper, we developed a methodology for managing investments in construction, as well as their control using modern BIM technologies. The effectiveness of using 3D modelling in investment control was demonstrated on the example of a residential complex. In addition, the volume of work obtained from the 3D-model was compared with the volume of work calculated manually. As a result, the exact amount of work and schedules for forecasting investment of funds were obtained.
\end{abstract}

\section{Introduction}

Investment in construction projects is a rather complex process. The customer of construction product, as a rule, is also its investor and for him the systematization of information about the construction process is a necessity [1-3]. The control process itself is closely related to the construction site, because the acceptance of installed structures and completed works must be carried out continuously at all stages of construction. The quality of the work done indirectly affects the functioning of the building and it must meet the stated requirements and meet all necessary requirements [4].

Construction investment control (CIC) is an integral part of the building construction process. Such control is a separate service that is necessary for the customer to objectively understand the installed work volumes and forecast deadlines [5-8]. Completed construction and installation works are confirmed by acts of acceptance of the completed works, which are subsequently the basis for payment for the work done [9].

\footnotetext{
* Corresponding author: monastyreva.de@edu.spbstu.ru
} 
Nowadays, the design process is in the process of switching to so-called BIM (Building Information Modelling or Building Information Model) technologies, which allow you to improve the quality of the received documentation, contain attribute data and subsequently apply such data and element geometry to obtain accurate specifications, calendar schedules, renderings, demonstration materials and design projects [10-13].

In addition to the above-mentioned ways of using BIM technologies, it is proposed to introduce them into the CIC process, which will simplify the interaction of technical supervision, the General Designer, as well as the construction organization and management Department, the economic Department [14-16]. As a rule, in such a chain of document flow, inaccuracies and errors may occur in determining the mounted volumes, which accordingly affects the financing and remuneration of labor [18-20]. The accuracy and correctness of such data is primarily necessary for the customer, the investor [21].

The purpose of this article is to increase of level of control of investment in construction and quality control documental process of completed construction works during the reporting period, based on accurate data on the composition and scope of work of a parametric model of the object.

As part of the goal, we are dealing with tasks such as:

1. Develop a methodology for managing investments in construction, as well as their control using modern BIM technologies

2. Formation of acts of acceptance based on information about the implementation of the construction and installation work and data on the volume of materials and structures obtained from the BIM model.

\section{Methods}

Construction control is performed in the Revit software environment. You can work with elements both from individual models and from assembled files. An assembly file is an information model that contains nested models. The volume of work in the BIM model corresponds to the actual volume (the error is not more than $1 \%$ ). The BIM model is one of the source data for investment control of construction. The BIM model is generated in the Autodesk Revit CAD system. Below are the stages of the CIC and responsible persons.

The use of sections to divide the text of the paper is optional and left as a decision for the author. Where the author wishes to divide the paper into sections the formatting shown in Table 2 should be used.

Table 1. CIC stages and responsible persons.

\begin{tabular}{|c|l|l|l|}
\hline № & \multicolumn{1}{|c|}{ Stage } & \multicolumn{1}{|c|}{ Responsible } \\
\hline 1 & $\begin{array}{l}\text { Acceptance of the model for compliance with the BIM } \\
\text { standard and elimination of comments }\end{array}$ & $\begin{array}{l}\text { Customer's BIM } \\
\text { manager/designer }\end{array}$ \\
\hline 2 & $\begin{array}{l}\text { Approval of construction control requirements for the } \\
\text { project/conclusion of a contract }\end{array}$ & Customer's BIM manager \\
\hline 3 & \multicolumn{2}{|l|}{ Preparing a model for construction control } & BIM construction support \\
\hline 4 & $\begin{array}{l}\text { Entering planned dates for construction and installation } \\
\text { works into the model }\end{array}$ & BIM construction support \\
\hline 5 & Monthly cycle: & $\begin{array}{l}\text { Dates of the } \\
\text { month }\end{array}$ & \\
\hline 5.1 & Construction and installation works & $01-25$ & Contractor \\
\hline 5.2 & $\begin{array}{l}\text { Reflection of the construction fact in the model } \\
\text { (volumes planned to be presented by the } \\
\text { contractor to the Customer for the reporting } \\
\text { period) - assigning dates and statuses to the }\end{array}$ & Until 20 & $\begin{array}{l}\text { BIM construction support } \\
\text { together with the } \\
\text { contractor }\end{array}$ \\
\hline
\end{tabular}




\begin{tabular}{|c|c|c|c|}
\hline & model elements & & \\
\hline 5.3 & $\begin{array}{l}\text { Preparation of the cumulative statement of the } \\
\text { with the fact of construction and installation } \\
\text { works }\end{array}$ & Until 21 & BIM construction support \\
\hline 5.4 & $\begin{array}{l}\text { Preparation of the detailed form of Act of } \\
\text { Acceptance - transfer to the customer's } \\
\text { technical supervision }\end{array}$ & Until 21 & BIM construction support \\
\hline 5.5 & $\begin{array}{l}\text { Control over the implementation of the } \\
\text { construction and installation works volumes } \\
\text { (determining the volume of construction and } \\
\text { installation works that the Customer is ready to } \\
\text { accept) }\end{array}$ & $\begin{array}{l}\text { From } 21 \text { to } \\
24\end{array}$ & $\begin{array}{l}\text { Technical supervision of } \\
\text { the customer, contractor, } \\
\text { BIM construction support }\end{array}$ \\
\hline 5.6 & $\begin{array}{l}\text { Update of the journal of the construction } \\
\text { works accumulative statement with the fact of } \\
\text { construction and installation works }\end{array}$ & Until 24 & BIM construction support \\
\hline 5.7 & $\begin{array}{l}\text { Preparation of detailed form of Act of } \\
\text { Acceptance - with the fact and forecasting the } \\
\text { implementation of future accounting periods }\end{array}$ & Until 24 & $\begin{array}{l}\text { BIM construction support } \\
\text { together with the } \\
\text { contractor }\end{array}$ \\
\hline 5.8 & $\begin{array}{l}\text { Preparation Of the enlarged form of first } \\
\text { construction acceptance certificate }\end{array}$ & Until 24 & BIM construction support \\
\hline 5.9 & $\begin{array}{l}\text { Preparation of an Enlarged form of second } \\
\text { construction acceptance certificates }\end{array}$ & Until 24 & BIM construction support \\
\hline 5.10 & $\begin{array}{l}\text { Creating and transmitting to the customer a } \\
\text { summary report for the month: documents on } \\
\text { acceptance of works types PDF }\end{array}$ & Until 24 & BIM construction support \\
\hline 5.11 & $\begin{array}{l}\text { Approval of the consolidated report for a } \\
\text { month }\end{array}$ & Until 25 & $\begin{array}{l}\text { Technical supervision of } \\
\text { the customer }\end{array}$ \\
\hline 5.12 & $\begin{array}{l}\text { Making a forecast of future accounting periods } \\
\text { in The customer's cumulative statements }\end{array}$ & & BIM construction support \\
\hline 5.13 & $\begin{array}{l}\text { Signing paper versions of the documents of } \\
\text { acceptance of works }\end{array}$ & & Director for construction \\
\hline 5.14 & \multicolumn{2}{|c|}{$\begin{array}{l}\text { Analysis of monthly performance and forecast of future } \\
\text { periods }\end{array}$} & Director for construction \\
\hline 6 & \multicolumn{2}{|c|}{ Completion of construction } & Contractor \\
\hline
\end{tabular}

1. Check BIM models for compliance with the BIM standard

Such verification is an essential part of the chain of work, because it significantly reduces the likelihood of errors at subsequent stages and, accordingly, improves the quality of the information that is being worked with. It is divided into 2 stages: checking for the correctness of the geometry and the tools used for modeling such geometry, as well as checking for the attribute content of elements, the availability of necessary parameters and their occupancy.

2. Creating a list of non-modeled jobs

The list of non-modeled works is necessary to include them in the General list of performed works (in the list of work volumes), followed by assigning prices for such types of work. The list of non-modeled works must be previously agreed with the customer and specified in the project implementation plan.

3. The creation of the bill of quantities

- Define scope of work

- Calculation of the duration, volume and cost of work

- Maintaining a hierarchical structure of types of construction and installation works

- Maintaining standard indicators of construction processes: 
- Time standards for estimating the duration of work

- Norms and prices for various details of the construction and installation work processes

- Labor costs

- Resource consumption per unit of work volume

- Maintaining a resource database

- Integration with calendar and network planning programs and other external systems

Figure 1 shows a tree of work types that displays the composition of complex and work processes.

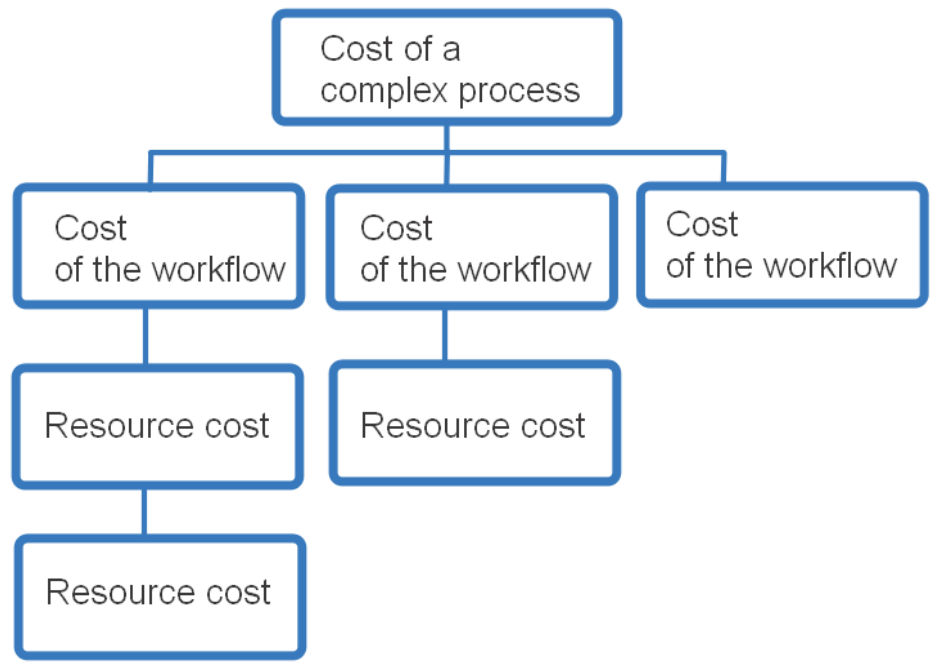

Fig. 1. Tree of types of work.

4. Uploading unit prices and planned dates to the BIM model.

Entering the agreed prices into the element parameters specially created for this purpose is also one of the most important stages of preparing the model for the CIC. Planned dates should also be included in the model elements.

Individual prices are loaded after Selecting and Contracting a contractor. Before that go:

- Formation and approval of tenders

- Conducting tender procedures. Comparison of submitted offers and selection of the winner

- Mapping of normative documents on the progress of the contractual relationship with the contractor

5. Unloading a bill of quantities

After all the parameters are filled in, the filtered elements are exported to Excel. The monthly cycle of investment control

Stages of the monthly cycle

- Photo recording of the construction site

- Entering data on work performed by the General contractor into the BIM model

- Approval of Completed works by the Customer's technical supervision service

- Formation of construction acceptance certificates forms

- Preparing a monthly report

6. The completion of the

During the control process, the so-called "status" is added to the model elements, which reflects the current status of the type of work on the construction site. Table 2 below shows the proposed statuses, their description, and color display in the model. 
Table 2. Statuses of model elements defined in the CIC process.

\begin{tabular}{|c|c|c|c|c|}
\hline \multicolumn{3}{|c|}{$\begin{array}{l}\text { Statuses defined in the framework of } \\
\text { construction con }\end{array}$} & Description & Color display \\
\hline \multicolumn{3}{|c|}{ NOT STARTED } & Work not started & \multirow[b]{2}{*}{ Grey/transparent } \\
\hline \multirow{4}{*}{ STARTED } & \multicolumn{2}{|c|}{ NOT BUILT } & $\begin{array}{l}\text { Work has started, the front of } \\
\text { subsequent work is not formed }\end{array}$ & \\
\hline & \multirow{3}{*}{ BUILT } & $\begin{array}{l}\text { Readiness IS less } \\
\text { than } 80 \%, 0 \% \text { is } \\
\text { accepted for the } \\
\text { act of acceptance } \\
\text { certificate }\end{array}$ & $\begin{array}{l}\text { The work is completed, the } \\
\text { front of subsequent work is } \\
\text { formed, the customer does not } \\
\text { accept work for registration in } \\
\text { the acts of acceptance and } \\
\text { payment }\end{array}$ & \\
\hline & & $\begin{array}{l}\text { Readiness from } \\
80 \% \text { TO } 99 \% \text {, } \\
95 \% \text { is accepted } \\
\text { for the act of } \\
\text { acceptance }\end{array}$ & $\begin{array}{l}\text { Work has begun, the front of } \\
\text { subsequent work has been } \\
\text { formed, the customer accepts } \\
\text { work for registration in the } \\
\text { acts of acceptance and } \\
\text { payment IS not in full, } \\
\text { structures need to be brought } \\
\text { to full construction } \\
\text { readiness/standards }\end{array}$ & Yellow \\
\hline & & $\begin{array}{l}100 \% \text { ready, } \\
100 \% \text { is } \\
\text { accepted for the } \\
\text { act of acceptance }\end{array}$ & $\begin{array}{l}\text { Work has started, the front of } \\
\text { subsequent work is formed, } \\
\text { the customer accepts work for } \\
\text { registration in the the acts of } \\
\text { acceptance and payment in full }\end{array}$ & Green \\
\hline
\end{tabular}

\section{Results and Discussion}

As an example, we consider the project of a residential complex, which is made in the level of detail LOD400. Figure 2 shows the General view of this building.

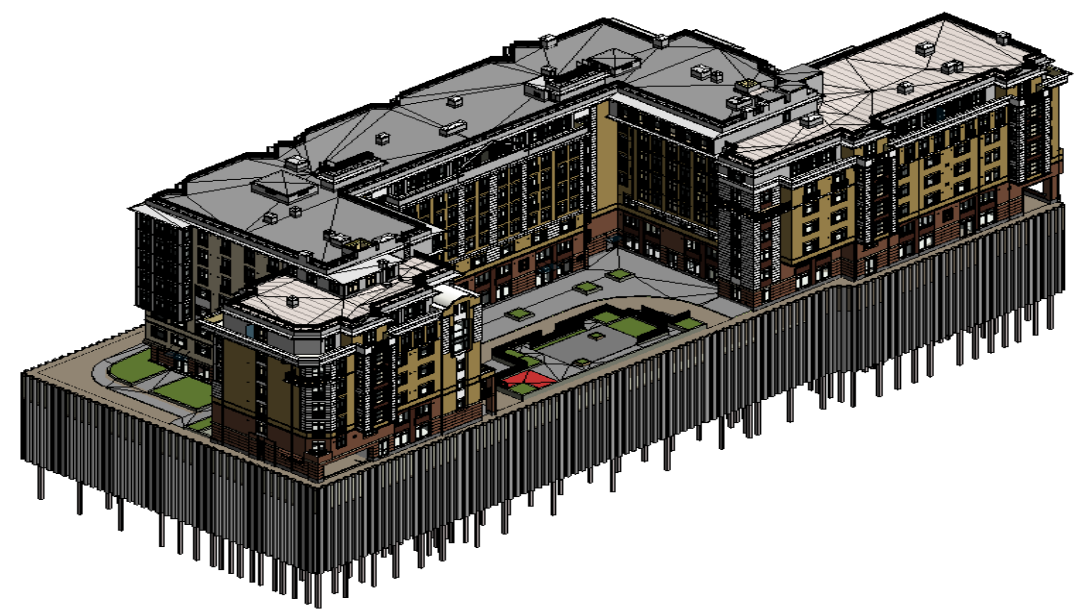

Fig. 2. General view of the building for the CIC. 
Model elements are related to their attribute content. Redefining the graphics in the view depends on the item's status value. The division into "statuses" is shown in table 2.

Thanks to the proposed CIC method, the customer can clearly see the installation process and the condition of the building elements. By updating the model after each check, you can monitor the construction process online. Figures 3 and 4 show the entire layout and building in accordance with the actual installation process on the site.
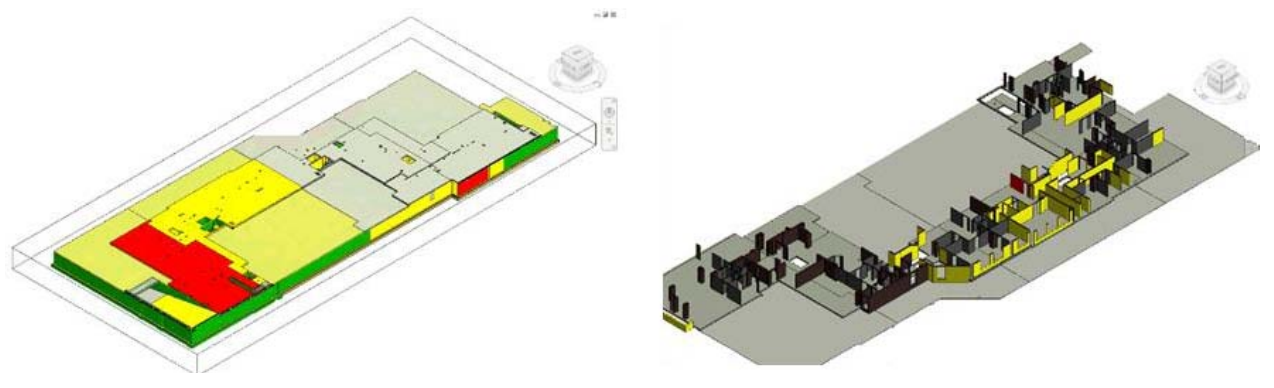

Fig. 3. Floor plans of the building in the process of conducting the CIC.
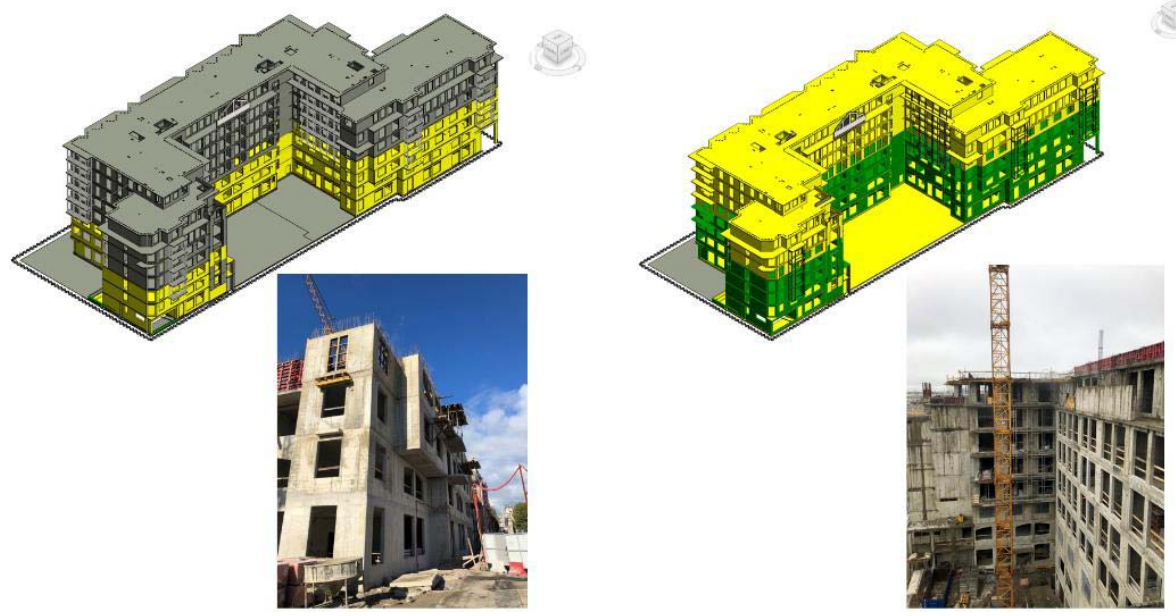

Fig. 4. Relations between elements in reality and the information model.

Another important result of the method of investment control of construction through the use of 3D models is the ability to plan the financial side. In the graphs in figure 5, you can see the dependence of the cash flow on time. This approach allows you to plan how much money you will need to invest in the next month. Such forecasting helps the customer determine the amount that they need to have in stock, which makes it possible to better control the economic component of the construction project. 

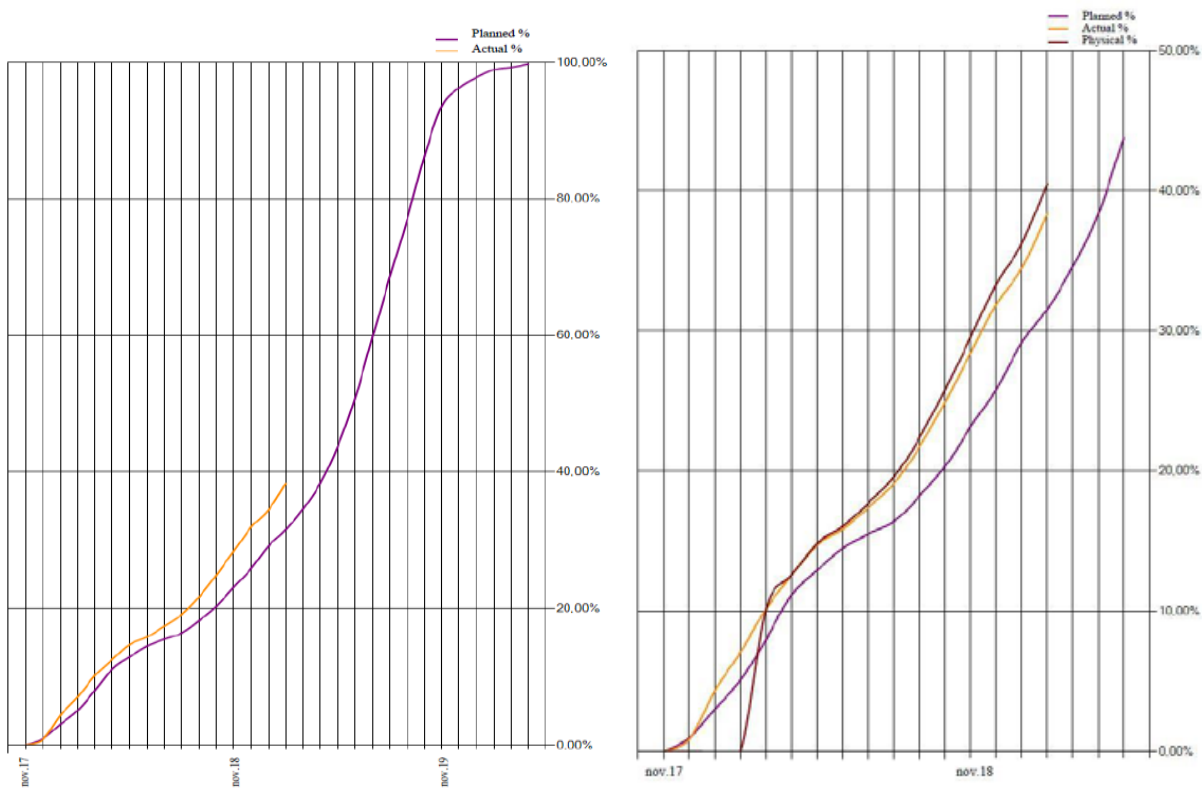

Fig. 5. Diagrams of dependence of investments from time to time.

Another advantage of using information modeling in CIC is an accurate estimation of the volume of structures and materials. Backfill was considered as an example. As shown in figure 6 , the volume of sand obtained from the model differs significantly from the volume calculated by "hands".

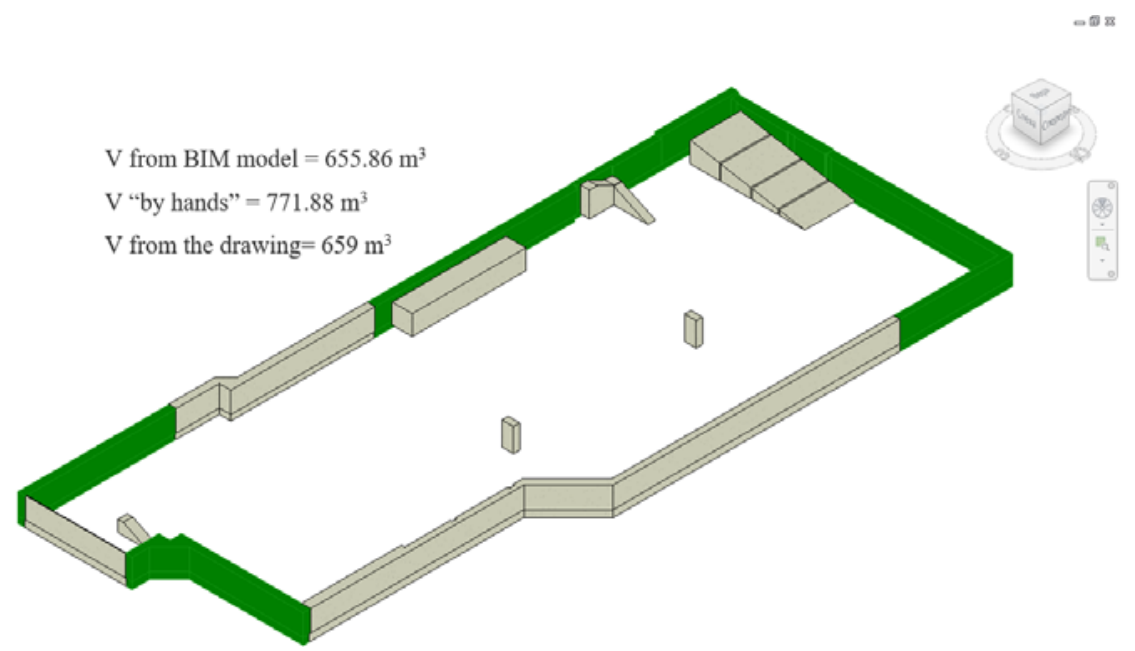

Fig. 2. Backfill volume data.

In figure 8 , we can see a comparison of data on the volume of backfill sand obtained from the construction site, from the model and from the drawing. As can be seen from figure 9, the data obtained from the model are most accurate as they take into account all the "bumps" allow "rounding" of volumes in favor of the contractor, which is an advantage for the customer, as he has the right to refer to the volumes calculated automatically from the model as the most reliable because there is no influence of the so-called human factor. 


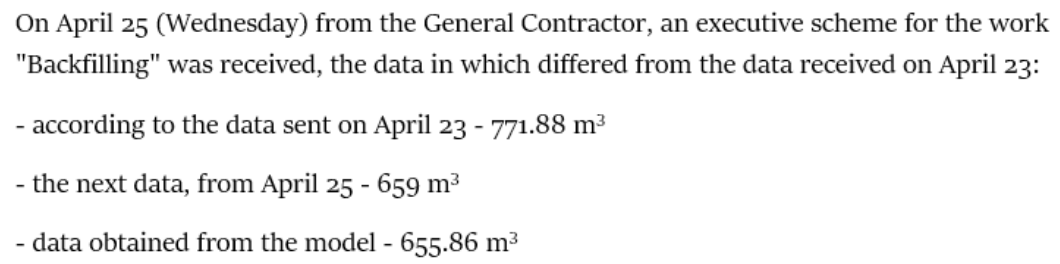

Fig. 3. Data on the volume of backfill sand obtained from the construction site, from the model and from the drawing.

\section{Conclusions}

BIM technologies can be successfully applied to the most important stage of construction investment control. As it was shown, the 3D model allows you to continuously monitor investment in construction, manage monetary resources, and predict their availability for the successful next closing of the reporting period.

The CIC methodology using the building information model was successfully developed and applied in the construction of a residential complex. accurate data from the BIM model allowed reducing the amount of money paid for the amount of work.

Advantages of using BIM for investment control:

- Reducing the risk of financial losses from unreliability of information about the actual volume of work performed;

- Increase the speed of preparation of work completion reports and investment control reports for construction;

- Getting reliable information about changes made to BIM models and project documentation;

- Creation of infrastructure for carrying out investment control procedures for construction to control subcontractors;

- Project cost estimation at each stage;

- Detailed calculation to the final structural element of the BIM model;

- Increasing the speed of building cost estimation;

- Reducing the impact of the human factor.

- The use of BIM technologies for CIC allows you to:

- Enter into a contract for a fixed price-minimizing the risks of additional work

- Build an accurate financial forecast and plan/fact comparison

- Automatically generate acts, keep cumulative records

- In the monthly report, you can clearly see the progress of construction ahead or behind (based on physical volumes and development of financial re-sources).

\section{References}

1. D. Arseniev, A. Rechinskiy, K. Shvetsov, N. Vatin, O. Gamayunova, Activities of Civil Engineering Institute to attract foreign students for training in civil engineering programs, Applied Mechanics and Materials (2014)

2. A.O. Asojo, Connecting Academia with Industry: Pedagogical Experiences from a Collaborative Design Project, Procedia - Soc. Behav. Sci. (2013)

3. F.G.B. Blanco, H. Chen, The Implementation of Building Information Modelling in the United Kingdom by the Transport Industry, Procedia - Soc. Behav. Sci. (2014) 
4. F.P. Cambeiro, F.P. Barbeito, I.G. Castaño, M.F. Bolíbar, J.R. Rodríguez, Integration of agents in the construction of a single-family house through use of BIM technology, Procedia Engineering (2014)

5. N. Chalfoun, Greening University Campus Buildings to Reduce Consumption and Emission while Fostering Hands-on Inquiry-based Education, Procedia Environ. Sci. (2014)

6. W.Y.B. Chiu, J.H.K. Lai, Building information modelling for building services engineering: benefits, barriers and conducive measures, Eng. Constr. Archit. Manag. (2020)

7. T. Ganbat et al., A Cross-Systematic Review of Addressing Risks in Building Information Modelling-Enabled International Construction Projects, Arch. Comput. Methods Eng. (2019)

8. M.A. Kristianto, N.A. Utama, A.M. Fathoni, Analyzing Indoor Environment of Minahasa Traditional House Using CFD, Procedia Environ. Sci. (2014)

9. A.N. Levandovskiy, B.E. Melnikov, A.A. Shamkin, Modeling of porous material fracture, Mag. Civ. Eng. (2017)

10. P. Mesaros, M. Spisakova, T. Mandicak, International Multidisciplinary Scientific GeoConference Surveying Geology and Mining Ecology Management, SGEM (2018)

11. D. Migilinskas, V. Popov, V. Juocevicius, L. Ustinovichius, The benefits, obstacles and problems of practical bim implementation, Procedia Engineering (2013)

12. S. Porter, Breaking into BIM: Performing static and dynamic security analysis with the aid of BIM, Autom. Constr (2014)

13. M. Ramesh Kannan, M. Helen Santhi, Constmctability assessment of climbing formwork systems using building information modeling, Procedia Engineering (2013)

14. M. Tender, J.P. Couto, C. Lopes et al., Occupational Safety and Hygiene VI - Selected contributions from the International Symposium Occupational Safety and Hygiene, SHO 2018 (2018)

15. K. Usanova, N. Vatin, Advances and Trends in Engineering Sciences and Technologies II - Proceedings of the 2nd International Conference on Engineering Sciences and Technologies, ESaT 2016 (2017)

16. N. Vatin, D. Nemova, L. Khazieva, D. Chernik, Distant learning course "energy efficient refurbishment management", Applied Mechanics and Materials (2014)

17. N.P. Romanov, O.V. Averyanova, A.G. Mkhitaryan, Construction of Unique Buildings and Structures 7(22) (2014)

18. N. Vatin, O. Gamayunova, D. Petrosova, Relevance of education in construction safety area, Applied Mechanics and Materials (2014)

19. O. Gamayunova, N. Vatin, Advanced Materials Research 1065 (2015)

20. A. Vysotskiy, S. Makarov, J. Zolotova, E. Tuchkevich, Features of BIM implementation using autodesk software, Procedia Engineering (2015) 